\title{
COVID-19 and the crisis of national development
}

\author{
The global practice of monetizing ecosystems to further national economic development has \\ laid fertile ground for the COVID-19 pandemic and others like it, writes Cobus van Staden.
}

Credit: Nicky Rehbock

C

OVID-19's rapid move from warning sign to global pandemic has yanked the spotlight onto a number of questions humanity has been uneasily avoiding for years. Beyond the human-focused ones like how to keep a global economy running when flights are shut down, it has also drawn attention to the human exploitation of ecosystems as national assets, which compels the human-animal interactions that probably made the virus infectious to humans in the first place.

While scientists around the world are engaged in furious detective work (https:// www.nbcnews.com/science/science-news/ where-did-new-coronavirus-come-pastoutbreaks-provide-hints-n1144521) and few concrete answers have emerged, it seems the virus was zoonotic: it jumped from animals to humans. The most likely suspect at the time this piece was written is bats. But while the virus is genetically similar to ones found in bats, those can't infect human cells. If the bat coronavirus is the source of the current outbreak, it must have mutated into its current form, probably via another animal. This transmitter animal is suspected to be the pangolin, a scaly anteater native to Asia and Africa. The pangolin is the world's most trafficked mammal (https://www.bbc.com/news/scienceenvironment-47200816), highly sought after in China and other Asian countries for its meat, and especially for its scales, which are used in traditional medicine. Because of this demand it faces a real danger of extinction.

The similarities between COVID-19 and pangolin-borne coronaviruses has focused attention on places where bats and pangolins may have spent time in close proximity. The most obvious suspect is the wildlife markets of Hubei, the Chinese province where the outbreak was first detected. The Chinese government has announced a 'comprehensive' ban on the trade and consumption (as food) of wildlife. This move has been praised by wildlife protection agencies worldwide, although many have pointed out that similar bans were quickly relaxed (https://ewn.co.za/2020/02/24/

china-comprehensively-bans-illegalwildlife-trade) after the SARS (severe acute respiratory syndrome) crisis in 2003.

They have also pointed out that many loopholes remain (https://www.nytimes. com/2020/02/27/science/coronaviruspangolin-wildlife-ban-china.html). The most glaring one here is that the ban doesn't extent to non-food wildlife products like pangolin scales. This leaves open potential avenues to infection and doesn't address the wider demand underlying the wildlife trade.

While the ban is encouraging, opinion is divided over whether the association with the outbreak will help (https://nationalpost. com/news/could-the-coronavirus-helpsave-pangolins-and-other-threatenedwild-animals) or harm (https://www.kiro7. $\mathrm{com} /$ news/local/coronavirus-could-edgepangolins-closer-extinction/4SIEG2K3 CNESPAPOIMM5VAJGE4/) the world's remaining pangolins. The ban won't do much to mitigate the current outbreak. It is more aimed at preventing the next virus from jumping the species barrier. COVID-19 is only the latest in a series of animal-related outbreaks, including the SARS epidemic and the MERS (Middle East respiratory syndrome) outbreak of 2012.

The ban is an imperfect and limited response to a much more fundamental issue: the destructive relationship between nature and development. One of the casualties of the ban has been 20,000 farms dedicated to breeding (https://www. theguardian.com/environment/2020/feb/25/ coronavirus-closures-reveal-vast-scale-ofchinas-secretive-wildlife-farm-industry) of wild species used in Chinese medicine and cuisine. These include everything from bamboo rats to civet cats (implicated in the 2003 SARS outbreak). The farms were originally promoted by the government as a way to develop poor rural communities via trade and ecotourism. The hurried ban on the trade and consumption of these species fits awkwardly with their previous status as initiatives to monetize traditional Chinese medicine in the pursuit of national development and rural uplift.
While the outbreak has turned Chinese communities around the world into targets of racist abuse, the reality is that similar initiatives have been embraced by governments around the world, be they attempts to make the products of traditional agriculture trendy or to foster ecotourism in rural areas.

The ban is encouraging in helping to address the fact that massive Chinese demand is driving some species to extinction, which is more a function of the size and wealth of China's middle class than any particular aspect of Chinese culture. Yet it can't do much to address the wider pressure driving governments around the world to monetize the few remaining functioning ecosystems under their jurisdiction. The COVID-19 crisis can't be separated from the wider question of what to do with the rural poor.

A good example of this dilemma is another slow-moving crisis related to Chinese medicine: the processing of donkey skin into a gelatine tonic called ejiao. As the popularity of ejiao increased among China's middle class, the country quickly ran out of donkeys, which in turn boosted similar international smuggling networks as those that ferry pangolins and other wildlife to China. Faced with rampant donkeynapping, African government reactions broke down into either banning the trade (https://www.bbc.com/news/worldafrica-51629660) to protect existing rural economies where donkeys are important beasts of burden or trying to set up donkey abattoirs (https://oxpeckers.org/2017/08/ namibias-donkey-slaughter-plans/) to foster new rural economies. That COVID-19 is not a donkey-borne virus is a mere accident of history.

As we cast about for a remedy to the current crisis, we should use it as a lens to look at a much wider one: where to go with the project of national economic development, perhaps the most consuming one of the modern era. The collision between globalized capitalism and the carving up of continental ecosystems into 'national assets' that function as fodder for 
a global race towards economic success has already driven humanity to the edge of a climate disaster. The current pandemic is a chapter in this wider story, one that is currently not destined to end well.
Cobus van Staden

Senior Researcher, South African Institute of International Affairs, Johannesburg, South Africa.

$\square \quad$ e-mail: Cobus.VanStaden@wits.ac.za
Published online: 23 March 2020

https://doi.org/10.1038/s41562-020-0852-7

Competing interests

The authors declare no competing interests. 